\title{
MODEL OF EVALUATION OF SUSTAINABILITY PERFORMANCE IN BUILDING PROJECTS INTEGRATING LEAN, THROUGH THE DELPHI METHOD
}

\author{
Xavier Brioso $^{1}$ and Fiorela Cruzado-Ramos ${ }^{2}$
}

\begin{abstract}
In recent years, sustainability management has become very important in order to achieve the goal that present and future generations can live in a better world, where economic, social and environmental aspects are balanced in harmony. On the other hand, there is a large amount of literature that shows that the application of Lean tools improves the indicators of work accidents and optimizes the management of resources in the project life cycle, making them more sustainable. In fact, experiences of the application of Lean principles and sustainable tools have been disseminated, but few studies have addressed a proposal for a framework or methodology that systematically integrates both approaches. This article presents a review of the literature of the main studies that address the implementation of Lean principles and environmental sustainability management. and proposes a model for evaluating sustainable management performance in building projects where Lean tools are implemented. The methodology used is based on a literature review, in which information was gathered from the documents of the International Conference on Lean Construction (IGLC) and a set of specialized journals on the topics of Lean Construction, Sustainable Management and key performance indicators (KPIs).This document aims to develop a model for evaluating the performance of Environmental sustainability, integrating Lean Construction and Sustainable Management in buildings, using the Delphi method, to reduce damage and unnecessary use of natural resources.
\end{abstract}

\section{KEYWORDS}

Lean Construction, Sustainable Management, Key Performance Indicators (KPIs), Delphi Method, Model

\section{INTRODUCTION}

In the literature review, Lean principles and practices are discovered to facilitate the achievement of environmental objectives (Vinodh et al. 2011). Thus, there is research on the level of integration or synergy between the implementation of the Lean philosophy and the management of sustainability, to carry out an evaluation of the environmental performance of construction projects. Although some authors have shown that the

1 GETEC Research Group, Department of Engineering, Pontifical Catholic University of Peru, Lima, Peru, xbrioso@pucp.edu.pe, orcid.org/0000-0002-0174-0241

2 GETEC Research Group, Department of Engineering, Pontifical Catholic University of Peru, Lima, Peru, fiorela.cruzado@pucp.edu.pe, orcid.org/0000-0003-3979-6838 
implementation of a range of Lean practices and tools have a positive effect on environmental variables (Moreira et al. 2010, Vinodh et al. 2011), the results are still inconclusive, both positive (Florida 1996, King and Lenox 2001) and negative (Rothenberg et al. 2001). Lean construction and sustainability are two philosophies, which emerged in different contexts, where their application was independent. However, there are currently studies that show that they are complementary (Carvajal et al. 2019, Francis et al. 2019, Dües et al. 2013) and that their integration achieves environmental benefits in projects (Martinez 2014, Khodeir and Othman 2016), since their synergy allows the optimization of resource management in all project phases (Martínez 2014, Dües et al. 2013).

The purpose of this research article is to present a model for evaluating the environmental sustainability performance of building projects, which integrate Lean philosophy and sustainability management, through the key performance indicators (KPI) and the use of the Delphi method.

\section{RESEARCH METHOD}

This study was developed based on a literature review of already published empirical and theoretical studies. The first stage involved the selection of magazines and publications containing topics related to Lean Construction, sustainable management and performance indicators, in order to identify what was most related to the field of this study. The conference proceedings of the International Lean Construction Group were included as a source of data, since there is published research that explains the influence of the implementation of Lean Construction on the reduction of damage and unnecessary use of natural resources. Finally, after an exhaustive review of the scientific literature associated with the key performance indicators, 50 scientific publications associated with the practices of LC, sustainability and/or the key performance indicators (KPIs) were compiled, with a focus on the different stages of the life cycle. The summary is shown in Table 1.

\section{INTEGRATION OF LEAN CONSTRUCTION AND SUSTAINABILITY}

The construction industry has the responsibility to contribute to the sustainable development of its projects, so it must embrace sustainability management in all phases of the project life cycle. There is a framework for managing the sustainability of projects, but it is necessary to establish that it not only involves the environmental factor, but also the economic and social categories (Ogunbiyi et al. 2014, Kibert 2016, Torres 2014, Solaimini 2019). However, it is important to indicate that the delimitation of this study corresponds to the evaluation of the environmental sustainability performance of building projects. Likewise, the Lean Construction philosophy aligned with the principles of Lean production, focuses on the implementation of tools and methodologies to improve production levels and minimize waste, thereby contributing to less use of natural resources (Koskela et al. 2002). Lean construction and sustainability are two philosophies, which emerged in different contexts, where their application was independent. However, there are currently studies that show that they are complementary (Carvajal et al. 2019, Francis et al. 2019, Dües et al. 2013) and that their integration achieves environmental benefits in projects (Martínez 2014, Khodeir and Othman 2016, Brioso and Patricio 2017, Brioso 2011), since their synergy allows the optimisation of resource management in all project phases (Martínez 2014, Dües et al. 2013). 
Table 1: Articles included in the literature review

\begin{tabular}{llll}
\hline $\mathbf{N}^{\circ}$ & Authors & $\mathbf{N}^{\circ}$ & Authors \\
\hline 1 & Alarcón (1996) & 26 & Khanzadi et al. (2018) \\
2 & Alarcón (2012) & 27 & Khodeir et al. (2018) \\
3 & Ali (2009) & 28 & Kylili (2016) \\
4 & Alwear (2009) & 29 & Lam et al. (2010) \\
5 & Bajjou (2018) & 30 & Latorre et al. (2010) \\
6 & Banihashemi et al. (2017) & 31 & LCl (2018) \\
7 & Bassioni et al. (2004) & 32 & Li et al. (2019) \\
8 & Babalola (2018) & 33 & Maradzano (2019) \\
9 & Butcher (2010) & 34 & Martínez (2014) \\
10 & Carvajal et al. (2019) & 35 & Nasir et al. (2012) \\
11 & Chan and Tam (2000) & 36 & Novak et al. (2012) \\
12 & Chan (2004) & 37 & Orihuela et al. (2016) \\
13 & Chan (2009) & 38 & Pitt and Tucker (2008) \\
14 & Cheung (2004) & 39 & Radujkovic et al. (2010) \\
15 & Constructing Excellence (2011) & 40 & Ramirez et al. (2004) \\
16 & Cox et al. (2003) & 41 & Rankin et al.(2008) \\
17 & Dawood (2010) & 42 & Ruoyu et al. (2019) \\
18 & Dwaikat (2018) & 43 & Saieg et al. (2018) \\
19 & Francis et al. (2019) & 44 & Shahin (2007) \\
20 & Hamel and Prahalad (1994) & 45 & Skibniewski (2009) \\
21 & Hammes et al.(2019) & 46 & Solaimini (2019) \\
22 & Horman et al. (2004) & 47 & Torres (2014) \\
23 & Hussain et al. (2019) & 48 & Yeung et al. (2013) \\
24 & Isa et al. (2018) & 49 & Zhang et al. (2014) \\
25 & Jamil and Fathi (2016) & 50 & Wu et al. (2013) \\
\hline & & &
\end{tabular}

Likewise, there are different investigations that show the synergy between the productivity and sustainability management systems, for example: (1) The Lean Construction philosophy and sustainable management seek to minimize waste and increase the efficiency of the project, considering Since each system has a different approach, the Lean philosophy presents results in short periods of time, while sustainable construction management is long-term, throughout the life cycle of the building project (Horman et al. 2004) . (2) The sustainability category and the Lean philosophy are compatible because, by reducing the use of energy and prioritizing environmental care, it allows reducing waste in the long term (Rothenberg et al. 2011). (3) Sustainability practices are the consequence of the application of the Lean philosophy in the construction phase of the project. (4) Lean Construction and sustainability implementations are compatible, therefore, companies that implement them in an integrated way could improve their efficiency and productivity indicators (Golzarpoor et al. 2013, Kim et al. 2007). (5) The level of integration between Lean philosophy and environmental sustainability is positive, because it reduces the indiscriminate use of resources and environmental pollution, by eliminating waste as much as possible and generating added value for the customer in form of lower environmental impact (Huovila 
Model of Evaluation of Sustainability Performance in Building Projects Integrating Lean, through the Delphi Method

and Koskela 1998, Riley et al. 2005, Sertyesilisik 2014, Solaimani and Sedighi 2019). (6) Both philosophies aim at waste reduction. Although each defines the term "waste" differently, both aim to eliminate excessive waste (waste considered in its broadest form) (Dües et al. 2013). (7) The Lean philosophy can help optimize the overall sustainability performance of the supply chain at different stages of construction and improve stakeholder engagement (Solaimini, 2019). (8) The implementation of Lean construction practices during the construction project generates positive effects on sustainability.

\section{KEY SUSTAINABILITY PERFORMANCE INDICATORS (KPIS)}

The literature shows that knowledge of key sustainability performance indicators plays a more important role than social and cultural incentives in their integration with project management practices (Zhang et al. 2014). As a popular proverb states, "If you can't measure it, you can't improve it" (Hamel and Prahalad 1994). The revolution in performance measurement has spread to many disciplines, including construction (Bassioni et al. 2004, Pitt and Tucker 2008). Fundamental studies revealed that time, cost and quality form the basis of these construction KPIs (Chan and Chan 2004). Recently, other factors such as safety (Chan et al. 2004) and sustainability have also been included (Lam et al. 2010). Environmental" KPIs are increasingly recognized as important aspects of the global sustainability agenda (Latorre 2010). The report by (Constructing 2011), revealed that environmental KPIs are making progress. The importance of measuring the performance of construction projects has led to several studies: for example, Alarcón (1996) proposes performance measurement classified by cost, expected value and effectiveness. At the same time, a study that aimed to identify critical factors of practices implemented in construction projects, found that by including an integrated model of key sustainability performance indicators, it enables a more sustainable construction industry. The most accepted indicators being those that allow physical measurement (Banihashemi et al. 2017, Cox et al. 2003). Finally, the evaluation and quantification of the performance of construction projects allow us to establish the level of success of the project in the terms in which it is being evaluated, for example, in this study we cover the evaluation of the performance of the environmental sustainability of the construction project.

\section{LIFE CYCLE OF THE PROJECT}

The construction industry represents an irreversible environmental impact on the natural environment, related to the consumption of resources, the use of energy and the generation of waste (United Nations Environment 2018). Therefore, it is necessary to address sustainable construction in the different phases of the project life cycle, that is, to help: (1) the reduction of energy consumption, (2) the reduction of waste, (3) the reduction of emissions into the atmosphere and (4) reuse and recycling (Carvajal et al. 2019).In the construction industry, there is a need to increase the performance of the construction process. Construction organizations are adopting various approaches (Hussain et al. 2019) such as ecological, Lean, life cycle assessment (LCA) and Six Sigma to increase sustainability (Dahlgaard et al. 2006), productivity (Ullah et al. 2017) and project quality (Dwaikat et al. 2018) and decrease life cycle cost (Chugani et al. 2017), manage project delays (Bajjou et al. 2018) and reduce waste.

Solaimani et al. (2019), indicate that it is important to analyze construction projects considering their complete life cycle and not only covering the construction phase, the following is an analysis of the different phases of a project: 


\section{DESIGN AND PLANNING}

The design phase is essential when it comes to setting environmental care objectives, since proper planning generates less use of resources. Likewise, the modular design that divides the project into work blocks can be promoted (Ghosh and Robson 2015, Hansen and Olsson 2011). The result appears to allow for more environmentally conscious design and planning, for example, contractors are encouraged to consider concrete recycling earlier in the design stage (Song and Liang 2011).

\section{CONSTRUCTION AND DELIVERY}

In the design and subsequent planning phase, the identification of key drivers of resource waste appears to be critical (Senaratne and Ekanayake 2012, Wu et al. 2013). In the design and subsequent planning phase, identifying the key drivers of resource waste appears to be critical (Senaratne and Ekanayake 2012, Wu et al. 2013). Therefore, it is necessary to redesign the current way of working in the construction industry, to achieve a low level of carbon emissions, through low inventory, continuous workflow, monitoring and regulating energy consumption to achieve zero net rating (Ladhad and Parrish 2013), reduce delivery time and minimize storage, while releasing less $\mathrm{CO} 2$.

The stages of construction and use, of the project life cycle, are associated with a greater impact on the environment. Therefore, the implementation of Lean Construction practices and sustainability management is necessary, since they produce positive effects on the environmental sustainability of the projects. However, there is little evidence on efficient integration for achieving Environmental sustainability during the construction and use phases of the Project (Carvajal et al. 2019).

\section{DELPHI METHOD}

The Delphi method seeks to obtain reliable group opinion from information provided by a panel of experts (Alshubbak et al. 2015), who are asked their individual views on various topics in a systematic and interactive way (Linstone and Turoff 1975). The data are obtained through a series of questionnaires. Through these questionnaires, the experts make their estimates anonymously in successive rounds in order to achieve maximum consensus while maintaining maximum autonomy of the participant (Cortés et al. 2012). The questionnaires can be distributed in person, by e-mail or on the Internet. The study leader or facilitator selects the experts according to a predefined pattern, develops questionnaires, analyzes the responses, and draws conclusions (Alshubbak et al. 2015).

The literature review has identified that the Delphi Method has been used to evaluate performance using indicators, including sustainable management indicators, in companies that can apply the Lean Construction philosophy (Luna et al. 2017, Arriola et al. 2018). On the other hand, many experts working in the public or private sector have contractual confidentiality restrictions for participating in surveys or face-to-face decision-making methods.

For these reasons, in this research, we will propose a model for performance evaluation of building projects that uses the Delphi method, leaving aside the fact that the model can be adapted to any collaborative and face-to-face decision-making method.

\section{PROPOSAL OF PERFORMANCE EVALUATION MODEL}

The proposed model comprises the following processes: (1) Identify the objective of the research, (2) Propose a methodology for evaluating the sustainability performance of building projects, (3) Validate the proposed methodology, (4) Apply the tool generated, 
Model of Evaluation of Sustainability Performance in Building Projects Integrating Lean, through the Delphi Method

(5) Evaluate results, (6) Report results. Figure 1 shows in graphic form the methodology described for the evaluation of Peruvian projects. The processes of the research methodology are explained next.

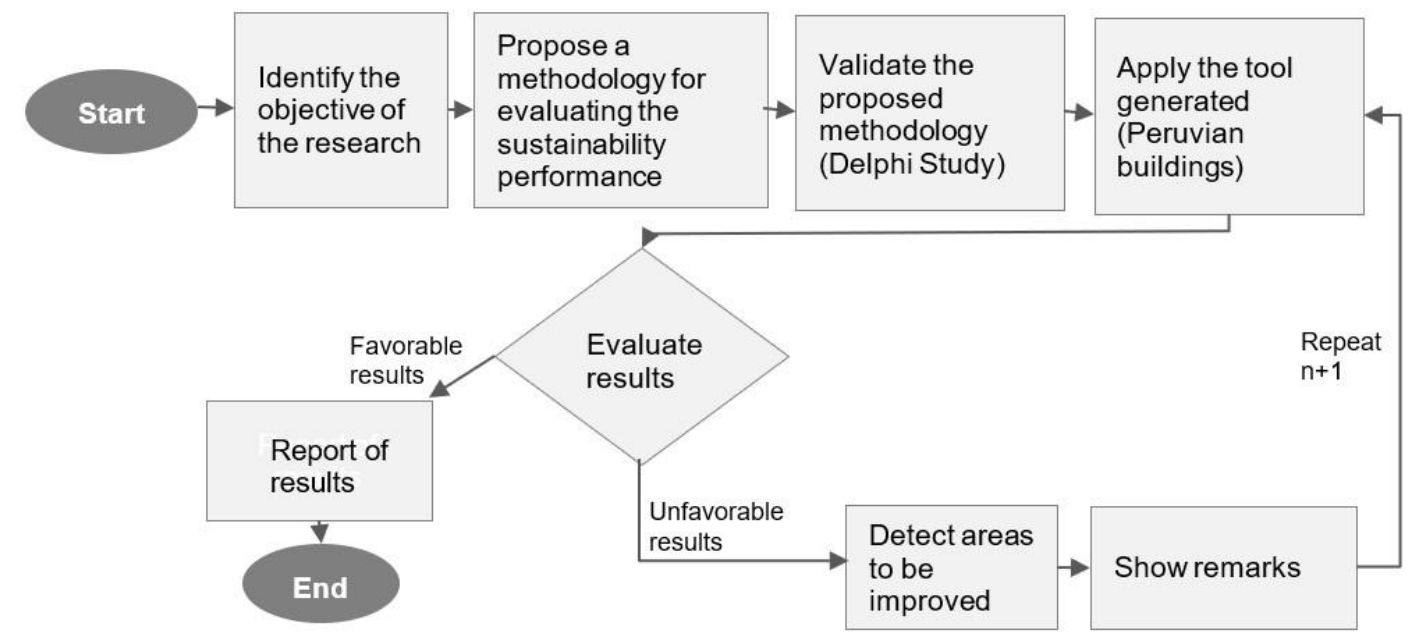

Figure 1: Processes of the research

\section{IDENTIFY THE OBJECTIVE OF THE RESEARCH}

At the beginning, the purpose of the research must be identified.

\section{Propose a MeThodology FOR EVAlUATING THE SUSTAINABILITY PERFORMANCE OF BUILDING PROJECTS}

After identifying the objective of the research, an initial proposal is intended for the evaluation of the sustainability of building projects through the measurement of key performance indicators (KPI's). Then, with the help of collaborating companies and the analysis of existing literature. Figure 2 graphically shows the procedure described.

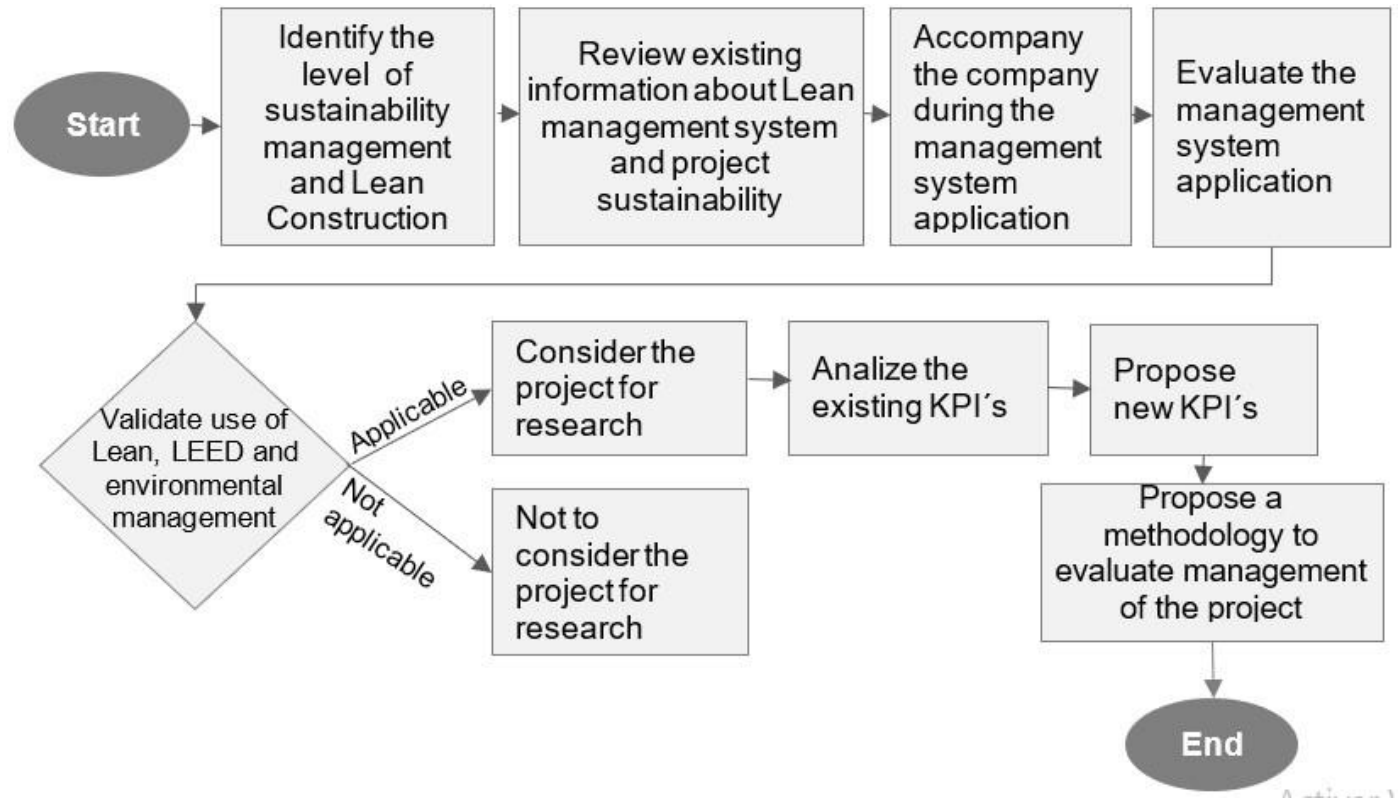

Figure 2: Propose an evaluation research 


\section{VALIDATE THE PROPOSED METHODOLOGY}

Once the proposal for the evaluation of the building projects has been established, a Delphi study is applied to revalidate the proposed tool, which allows the evaluation of sustainability performance of building projects, through the use of key performance indicators (KPI's). A flow chart that summarizes the methodology is shown in Figure 3.

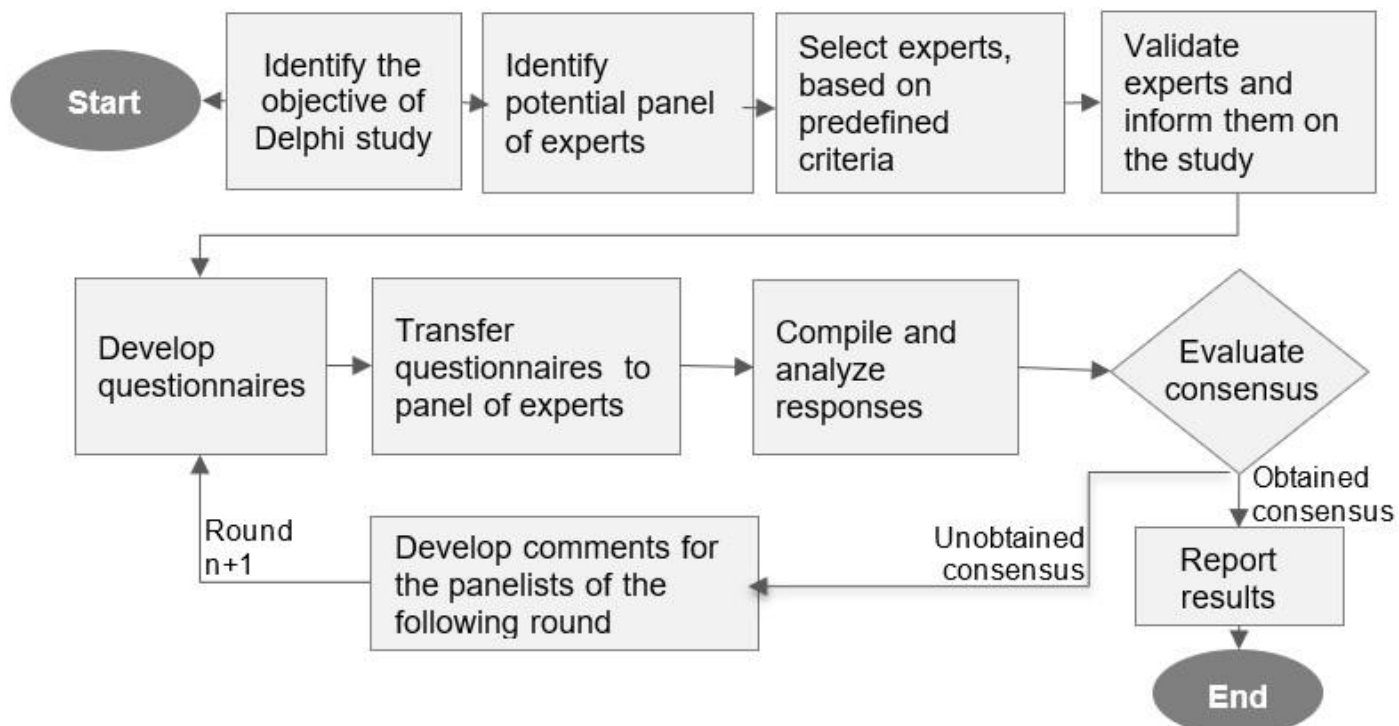

Figure 3: Validate the proposed methodology (Delphi Study)

\section{APPLY THE TOOL GENERATED}

After validating the proposed tool through the Delphi study, the sustainability performance evaluation methodology is applied to building projects in Peru, in order to obtain quantitative results in relation to their key performance indicators of sustainability (KPI's). Figure 4 shows a flow chart that allows a better understanding of the procedures followed in this section.

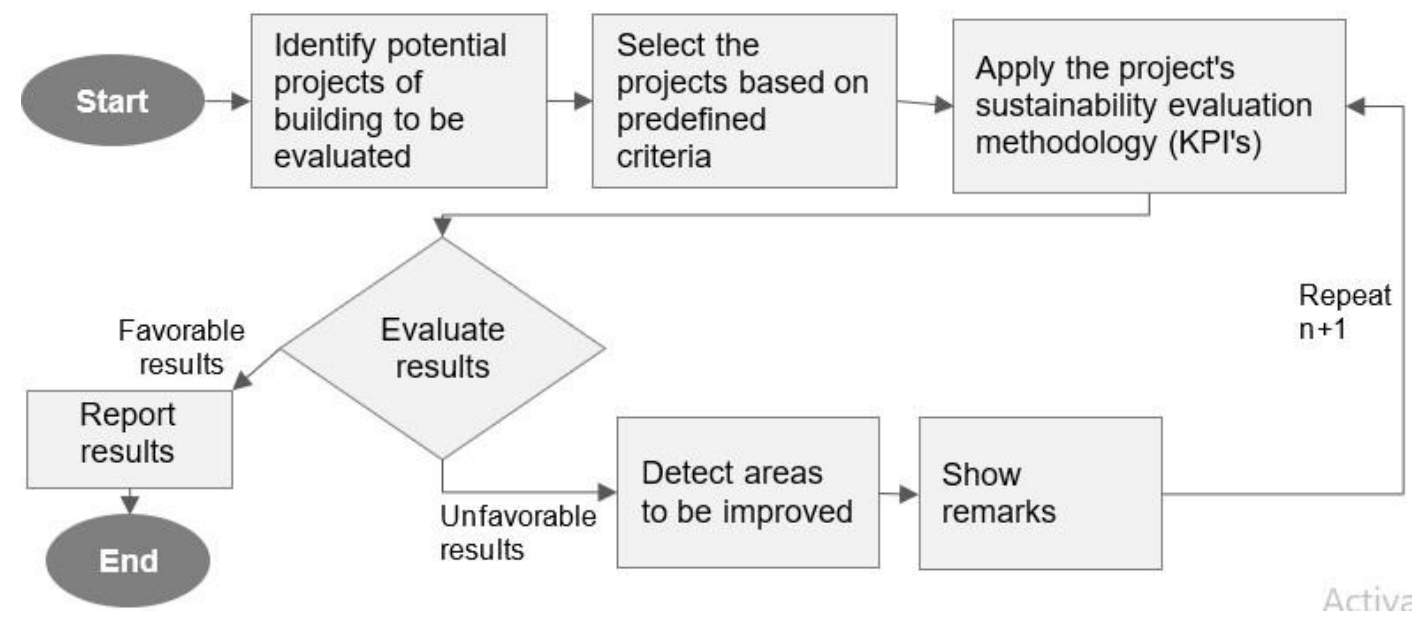

Figure 4: Apply the tool 
Model of Evaluation of Sustainability Performance in Building Projects Integrating Lean, through the Delphi Method

\section{EVALUATE RESULTS}

After applying the evaluation tool to the different building projects, we proceed to evaluate the results obtained, to finally issue an evaluation report.

\section{REPORT OF RESULTS}

The results obtained for the different projects are analyzed, and if deficient management practices are detected, improvement alternatives are suggested in order to optimize the sustainability performance of the building projects.

\section{CONCLUSIONS}

Several studies related to Lean Construction and sustainable management have been carried out, particularly in the construction phase. The literature review conducted indicated that the number of documents focusing on how Lean Construction has been used as a strategy for the reduction of damage and unnecessary use of natural resources used in buildings is relatively limited because its application is relatively new.

Regarding the proposed performance evaluation model, recent studies were found where the participation of stakeholders to validate the indicators proposed for the evaluation is fundamental, especially with the use of the Delphi method (Luna et al. 2017, Arriola et al. 2018). This is because the opinion of various specialists in the public or private sector may be contractually limited by confidentiality clauses, so the application of the Delphi method is ideal for ensuring the anonymity of contributions. In any case, the proposed model can be adapted to other collaborative decision-making methods of group and open participation.

The main contribution of this document is that it meets the objective of providing a state of the art in the integration of Lean Construction and Sustainable Management in buildings that apply Lean tools, and includes a model for evaluating environmental sustainability performance through key performance indicators (KPI's) and the use of the Delphi method.. Also, the article encourages the application of the Lean Construction philosophy, starting with the tools of the Last Planner System, as a strategy to reduce the damage and unnecessary use of natural resources, in order to have a more sustainable world for present and future generations.

\section{REFERENCES}

Aigbavboa, C., Ohiomah, I., Zwane, T. 2017. "Sustainable construction practices: 'a lazy view' of construction professionals in the South Africa construction industry." Energy Procedia 105, 3003-3010.

Alarcón, L.F. 1996. "Last Planner® System.” GEPUC, Pontificia Universidad Católica de Chile.

Alarcón, L.F. 2012. "Last Planner® System.” GEPUC, Pontificia Universidad Católica de Chile.

Ali, H.H. and Al Nsairat, S.F. 2009. "Developing a green building assessment tool for developing countries - case of Jordan.” Building and Environment, 44, 1053-1064.

Alwear, H. and Clements-Croome, D. 2009. "Key performance indicators (KPIs) and priority setting in using the multi-attribute approach for assessing sustainable intelligent buildings.” Building and Environment, 26 08, pp. 790-807. 
Arriola, B., Denis, A., and Rodríguez, S. 2018.“An initial evaluation of a method for adopting kaizen events in the construction sector." Construction Engineering Journal, 33(2), 173-182.

Babalola, O., Ibem, E.O., and Ezema, I. C. 2018. "Implementation of lean practices in the construction industry: A systematic review." Building and Environment.

Bajjou, M., Chafi, A. 2018. "Lean construction implementation in the Moroccan construction industry: awareness, benefits and barriers." J. Eng. Des. Technol. 16(4) 533-556.

Banihashemi, S., Hosseini, M. R., Golizadeh, H., and Sankaran, S. 2017. "Critical success factors (CSFs) for integration of sustainability into construction project management practices in developing countries." Int. J. of Project Management, 35(6), 1103-1119.

Brioso, X. 2011. “Applying Lean Construction to Loss Control.” In: Rooke, J. and Dave, B., Proc. 19th Ann. Conf. Int. Group for Lean Construction, Lima, Peru, 13-15 Jul.

Brioso, X. and Patricio, W. 2017. "Identification and evaluation of satisfaction degree in the post-occupation phase of the economic housing projects from the perspective of the users: Peruvian case study." Anales de Edificación, 3 (2) 17-26, ISSN: 2444-1309.

Butcher, D. C. A. and Sheehan, M. J. 2010. "Excellent contractor performance in the UK construction industry." Engineering, Construction and Architectural Management, 17(1), 35-45.

Carvajal-Arango, D., Bahamón-Jaramillo, S., Aristizábal-Monsalve, P., VásquezHernández, A., and Botero Botero, L. F. 2019. "Relationships between lean and sustainable construction: Positive impacts of lean practices over sustainability during construction phase." Journal of Cleaner Production.

Chan, A.P. and Tam, C.M. 2000. "Factors affecting the quality of building projects in Hong Kong." Int. J. of Quality and Reliability Management, 17(4-5), pp. 423-442.

Chan, A.P.C., Chan, A.P.L. 2004. "Key performance indicators for measuring construction success.” Benchmarking: An International Journal, 11(2), 203-221.

Chan, T. K. 2009. "Measuring performance of the Malaysian construction industry." Construction Management and Economics, 27(12), 1231-1244.

Chugani, V., Kumar, J.A., Garza-Reyes, L., and Rocha-Lona, A. 2017. "Upadhyay, Investigating the green impact of lean, six sigma and lean six sigma: a systematic literature review." Int. J. Lean Six Sigma, 8 (1) 7-32.

Constructing Excellence 2011. "Industry Performance Report 2011." London, Reino Unido.

Cox, R., Ahrens, D. 2003. "Management's perception of key performance indicators for construction." Journal of Construction Engineering and Management, 129(2), 142151.

Dahlgaard, J, Mi Dahlgaard-Park, S. 2006. "Lean production, six sigma quality." TQM and company culture, TQM Mag. 18 (3) 263-281.

Dawood, N., Sikka, S. 2010. "Development of 4D based performance indicators in construction industry." Engineering, Construction and Architectural Management, $16(5), 438-458$.

Dües, C.M., Tan, K.H., Lim, M. 2013. "Green as the new Lean: how to use Lean practices as a catalyst to greening your supply chain." J. Clean. Prod. 40, 93-100.

Dwaikat, K.N. Ali. 2018 . "Green buildings life cycle cost analysis and life cycle budget development: practical applications." J. Build. Eng., 18 303-311.

Florida, R. 1996. "Lean and green: The move to environmentally conscious manufacturing." Calif Manage. 
Model of Evaluation of Sustainability Performance in Building Projects Integrating Lean, through the Delphi Method

Francis, A., and Thomas, A. 2019. "Exploring the relationship between lean construction and environmental sustainability: - A review of existing literature to decipher broader dimensions." Journal of Cleaner Production.

Ghosh, S., Robson, K.F. 2015. "Analyzing the Empire state building project from the perspective of lean delivery system: a descriptive case study." Int. J. Constr. Educ. Res. 11 (4), 257e267 (*).

Golzarpoor, H., Gonzalez, V. 2013. “A green-lean simulation model for assessing environmental and production waste in construction." Proc. 21st Ann. Conf. Int. Group for Lean Construction, pp. 885-894.

Hamel, G. and Prahalad, C.K. 1994. Competing for the Future. Harvard Business School Press, Boston, MA.

Hammes G, De Souza, E.D., Taboada Rodriguez, C.M., Rojas Millan, R.H., and Mojica Herazo, J.C. 2019. "Evaluation of the reverse logistics performance in civil construction." Journal of Cleaner Production.

Hansen, G.K., Olsson, N.O. 2011. "Layered project, layered process: lean thinking and flexible solutions." Architect. Eng. Des. Manag. 7 (2), 70e84 (*).

Horman, M., Riley, D., Pulaski, M., Leyenberger, C. 2004. "Lean and green: integrating sustainability and lean construction.” In: CIB World Build. Congr., pp. 1-10.

Huovila, P., Koskela, L. 1998. "Contribution of the principles of lean construction to meet the challenges of sustainable development." Proc. 6th Ann. Conf. Int. Group for Lean Construction, pp. 13-15

Hussain, K., He, Z., Ahmad, N., Iqbal, M., and Taskheer mumtaz, S. M. 2019. "Green, lean, Six Sigma barriers at a glance: A case from the construction sector of Pakistan." Building and Environment.

Isa, R., Emuze, F., Das, D., and Awuzie, B. O. 2018. "Modeling a transformational route to infrastructure sustainability in South Africa." Built Environment Project and Asset Management, 8(2), 147-159. doi:10.1108/bepam-11-2016-0070.

Jamil, A. H. A., and Fathi, M. S. 2016. "The Integration of Lean Construction and Sustainable Construction: A Stakeholder Perspective in Analyzing Sustainable Lean Construction Strategies in Malaysia." Procedia Computer Science, 100, 634-643.

Khanzadi, M., Sheikhkhoshkar, M., and Banihashemi, S. (2018). "BIM applications toward key performance indicators of construction projects in Iran." International Journal of Construction Management.

Khodeir, L. M. and Othman, R. 2016. "Examining the interaction between lean and Sustainability principles in the management process of AEC Industry." Ain Shams Engineering Journal.

Kibert, C.J. 2016. "Sustainable Construction: Green Building Design and Delivery," fourth ed., 4th. John Wiley \& Sons.

Kim J-W, Bae Youg-Woo. 2007. "Sustainable value in construction project and application of lean construction method." Proc. 15th Ann. Conf. Int. Group for Lean Construction, Michigan, USA.

Koskela, L., Ballard, G., Howell, G., Tommelein, I. 2002. "The foundations of lean construction." Des. Constr. Build. Value $211 \mathrm{e} 226$ no. December 2015.

Kylili, A., Fokaides, P.,Lopez, P. 2016. "Key Performance Indicators (KPIs) approach in buildings renovation for the sustainability of the built environment: A review. Renewable and Sustainable Energy" Reviews, 56:906-915

Ladhad, A., Parrish, K. 2013. "Phoenix's first net-zero energy office retrofit: A green and lean case study." J. Green Build. https://doi.org/10.3992/jgb.8.4.3 
Lam, P. T. I., Chan, E. H. W., Poon, C. S., Chau, C. K., and Chun, K. P. 2010. "Factors affecting the implementation of green specifications in construction." Journal of Environmental Management, 91(3), 654-661.

Latorre, V., Roberts, M., Riley, M.J. 2010. "Desarrollo de un marco de sistemas dinámicos con KPIS para apoyar la toma de decisiones de los administradores de obra." Revista de la Construcción, 9(1), 39-49.

Li, L., Li, Z., Li, X., Zhang, S., and Luo, X. 2019. “A new framework of industrialized construction method in China: Towards on-site industrialization." Journal of Cleaner Production, 118469.

Linstone, H.A. and Turoff, M. 1975. "The Delphi method: techniques and applications." Addison-Wesley, London.

Luna, K., Pellicer, E., and García, S. 2017. "Performance indicators for developer and homebuilder Mexican companies: A Delphi study." Construction Engineering Journal, vol. 16, núm. 1, pp. 133-144.

Maradzano, L., Dondofema, R.A., Matope S. 2019. "Application of lean principles in the South African Construction Industry." South African Journal of Industrial Vol 30(3) Special Edition

Martínez-Jurado, P.J., Moyano-Fuentes, J. 2014. "Lean management, supply chain management and sustainability: a literature review." J. Clean. Prod. 85, 134e150. McQuad

Moreira, F., Alves, A. C., and Sousa, R. M. 2010. "Towards Eco-efficient Lean Production Systems." IFIP Adv. in Information and Communic. Technology, 100-108.

Nasir, H., Haas, C. T., Rankin, J. H., Fayek, A. R., Forgues, D., Ruwanpura, J. 2012. "Development and implementation of a benchmarking and metrics program for construction performance and productivity improvement." Canadian Journal of Civil Engineering, 39(9), 957-967.

Novak, V.M. 2012. "Value paradigm: Revealing synergy between lean and sustainability." Proc. 20th Ann. Conf. Int. Group for Lean Construction.

Ogunbiyi, O. 2014. "Implementation of the Lean Approach in Sustainable Construction: A Conceptual Framework." Grenfell-Baines School of Architecture, Construction and Environment. Lancashire, UK: University of Central Lancashire.

Orihuela, P., Pacheco, S., Aguilar., Orihuela, P. 2016. "Conference: ELAGEC." At Bogotá, Colombia, Volume: VII

Pitt, M. and Tucker, M. 2008. "Performance measurement in facilities management: driving innovation?” Property Management, Vol. 26 No. 4, pp. 241-54.

Radujković, M., Vukomanović, M., Burcar Dunović, I. 2010. "Application of key performance indicators in south-eastern European construction." Journal of Civil Engineering and Management, 16(4), 521-530.

Ramírez, R. R., Alarcón, L. F., and Knights, P. 2004. "Benchmarking system for evaluating management practices in the construction industry." Journal of Management in Engineering, 110-117.

Rankin, J., Fayek, A. R., Meade, G., Haas, C., Manseau, A. 2008. "Initial metrics and pilot program results for measuring the performance of the Canadian construction industry." Canadian Journal of Civil Engineering, 35(9), 894-907.

Rothenberg S, Pil FK, Maxwell J. 2011. "Lean, green and the quest for superior performance.” J. Prod. Oper. Manag., 10(3):228-43.

Rothenberg, S., Pil, F.K., Maxwell, J. 2001. "Lean, green, and the quest for superior environmental performance.” J. Prod. Oper. Manag., 10, 228-243. 
Model of Evaluation of Sustainability Performance in Building Projects Integrating Lean, through the Delphi Method

Ruoyu Jin , Jingke Hong, Jian Zuo. 2019. "Environmental performance of off-site constructed facilities: A critical review." Energy \& Buildings.

Saieg, P., Sotelino, E. D., Nascimento, D., and Caiado, R. G. G. 2018. "Interactions of Building Information Modeling, Lean and Sustainability on the Architectural, Engineering and Construction industry: A systematic review." Journal of Cleaner Production

Salem, O., Solomon, J., Genaidy, A. and Minkarah, I. 2006. "Lean construction: From theory to Implementation." Journal of Management in Engineering, 22(4), 168-175.

Senaratne, S., Ekanayake, S. 2012. "Evaluation of application of lean principles to precast concrete bridge beam production process.” J. Archit. Eng. 18 (2), 94e106(*).

Shahin, A. 2007. "Simulation of cold weather construction." PhD thesis, Univ. of Alberta, Edmonton, AB, Canada.

Skibniewski, M.J., Ghosh, S. (2009). "Determination of key performance indicators with enterprise resource planning systems in engineering construction firms." Journal of Construction Engineering and Management, 135(10), 965-978.

Solaimani, S., and Sedighi, M. (2019). "Toward a holistic view on Lean sustainable construction: a literature review." Journal of Cleaner Production

Song, L., Liang, D., (2011). "Lean construction implementation and its implication on sustainability: a contractor's case study." Can. J. Civ. Eng. 38 (3), 350e359.

Torres, N., (2014). "Study of Sustainability Opportunities during Construction. United Nations Environment." Sustainable Buildings, p. 31

Ullah, M.J. Thaheem, S.Q. Siddiqui, M.B. Khurshid (2017), "Influence of Six Sigma project success in construction industry of Pakistan." TQM J. 29 (2), 276-309.

United Nations Environment 2018. Sustainable Buildings, p. 31 [Online]. Available: https://www.unenvironment.org/explore-topics/resource-efficiency/what-weo/cities/sustainable-buildings.

Vinodh, S., Arvind, K.R., Somanaathan, M. 2011. "Tools and techniques for enabling sustainability through lean initiatives." Clean Technol. Environ. Policy 13, 469-479.

Wu, P., Low, S.P., Jin, X. 2013. "Identification of non-value adding (NVA) activities in precast concrete installation sites to achieve low-carbon installation." Resour. Conserv. Recycl., 81, 60e70 (*).

Yeung, J. F, Chan, A. P., Chan, D. W., Chiang, Y. H., Yang, H. 2013. "Developing a benchmarking model for construction projects in Hong Kong." Journal of Construction Engineering and Management, 139(6), 705-716.

Zhang, X. Skitmore, M. Peng, Y. 2014. "Exploring the challenges to industrialized residential building in China." Habitat International, 41 176-184. 